\title{
Influence of high gravity process conditions on the environmental impact of ethanol production from wheat straw
}

\author{
Matty Janssen ${ }^{\mathrm{a}, *}$, Anne-Marie Tillman ${ }^{\mathrm{a}}$, David Cannella ${ }^{\mathrm{b}}$, Henning Jørgensen ${ }^{\mathrm{b}, 1}$ \\ ${ }^{a}$ Environmental Systems Analysis, Department of Energy and Environment, Chalmers University of Technology, SE-412 96 Göteborg, \\ Sweden \\ ${ }^{b}$ Forest and Landscape, University of Copenhagen, Frederiksberg C, DK-1958, Denmark
}

\begin{abstract}
Biofuel production processes at high gravity are currently under development. Most of these processes however use sugars or first generation feedstocks as substrate. This paper presents the results of a life cycle assessment (LCA) of the production of bio-ethanol at high gravity conditions from a second generation feedstock, namely, wheat straw. The LCA used lab results of a set of 36 process configurations in which dry matter content, enzyme preparation and loading, and process strategy were varied. The LCA results show that higher dry matter content leads to a higher environmental impact of the ethanol production, but this can be compensated by reducing the impact of enzyme production and use, and by polyethylene glycol addition at high dry matter content. The results also show that the renewable and non-renewable energy use resulting from the different process configurations ultimately determine their environmental impact.
\end{abstract}

Keywords: high gravity hydrolysis and fermentation, wheat straw, life cycle assessment, energy analysis

\section{Introduction}

The development of sustainable processes for the production of biofuels is an ongoing effort. The bioethanol industry has taken initiatives to improve the energy and material efficiency of the existing bio-ethanol production technologies with the goal to make these more cost competitive. One way to reach this goal is to run the hydrolysis and fermentation processes at high gravity conditions, that is, at high concentrations of substrate. This results in a reduction of water use in the process and a higher concentration of ethanol in the fermentation broth. Consequently, a reduction in the energy needed during the downstream processing of the broth is achieved (Jørgensen et al., 2007). However, the development of such high gravity processes has mostly been done using sugars derived from starch or sucrose containing crops such as grains, corn, sugar cane or

\footnotetext{
*Corresponding author

Email address: mathias. jans sen@ chalmers. se (Matty Janssen)

${ }^{1}$ Current address: Center for Bioprocess Engineering, Department of Chemical and Biochemical Engineering, Building 229, Technical University of Denmark, DK-2800 Kgs. Lyngby, Denmark
} 
sugar beet (Puligundla et al., 2011). Due to concerns about the possible competition with food production, a hydrolysis and fermentation process using a second generation feedstock is a possible technology development pathway. Koppram et al. (2014) reviewed the challenges and perspectives regarding ligno-cellulosic ethanol production at high gravity conditions. The main challenges that need to be dealt with are a) high concentrations of inhibitory substances that are released during the pretreatment of the feedstock, $b$ ) high concentrations of sugars and ethanol which in themselves are inhibitory, and c) the high viscosity of the pretreated material in the hydrolysis and fermentation step which results in mixing and mass transfer limitations. These challenges are currently investigated for the production of ethanol from wheat straw (Cannella et al., 2012; Cannella and Jørgensen, 2014) and the results of this research form the basis of the work presented in this paper. One country that has pioneered the use of straw is Denmark. Besides its use for bedding and forage, approx. 1.3 Mt of straw per year was used in Denmark on average for energy purposes during the period 2004-2008 (which is approx. 25\% of the available straw). Its resource potential has not yet been fully exploited (on average $38 \%$ was not used over that same period), due to economic restrictions such as the cost of handling and transportation of the straw (Skøtt, 2011). Furthermore, in the European Union agricultural residues such as wheat straw are readily available, but are not projected to either become more or less abundant until 2050 (Bentsen and Felby, 2012). This may lead to an increase in the price of straw if demand increases. Another factor that limits the use of straw is the common practice to leave a certain amount of harvestable straw in the field. This is done in order to maintain the soil carbon pool, and to prevent greenhouse gas emissions from the soil (Cherubini and Ulgiati, 2010).

Life cycle assessment (LCA) is a technique for assessing the environmental aspects and potential impacts associated with a product throughout its life cycle (International Organization of Standardization, 2006). LCA has been applied extensively to assess second generation bio-ethanol production from different kinds of feedstocks. These assessments have generally been done using data that describe industrial-scale operations (for instance from the well-known NREL studies (Aden et al., 2002; Humbird et al., 2011)) and thus assess the bio-ethanol life cycle at a mature development stage. LCA can however also be used to assess the environmental impacts of a new process technology along its development path. Shibasaki et al. (2007) developed a method to employ LCA for the assessment of technologies that are at an early stage of development, and pointed out that scale-up effects cannot be neglected when such a technology is compared to a technology that already runs at an industrial scale. Besides scale issues, Hillman and Sandén (2008) also considered time aspects when performing an LCA of large-scale technical systems. They identified the shifting time frame and changes in the background system as issues that are given little attention. Considering the shifting time frame in LCA 
through doing several assessments during a period of time instead of doing one assessment as a snapshot in time, for instance at the end of the projected development period, would give room for modelling technical development such as improved performance, and perhaps even a changed function of the product. For instance, bio-ethanol may over time be used as a building block chemical for the production of bio-polyethylene (Liptow and Tillman, 2012; Liptow et al., 2013) instead of as a fuel which would change the function of the ethanol production system, and may thus change the functional unit. Additionally, the background system may change over time due to changes in e.g. a country's energy mix, but may also change due to the scale at which a new technology is applied, e.g. increased land use due to increased biofuel production. Cherubini and Strømman (2011) pointed out in their review of LCA studies of bioenergy systems that most of them included global warming potential and energy use in the impact assessment. These energy analyses evaluated all energy inputs along the life cycle resulting in the cumulative primary energy demand of a product. Little mention was made of a more detailed view on these energy flows to evaluate, for instance, how much energy is contained in the main product and by-products. A minority of the reviewed studies included categories like acidification and eutrophication. As well, only few studies considered land use and land use change in their impact assessment due to the lack of a widely accepted impact assessment methodology.

The purpose of the life cycle assessment described in this paper was to assess the environmental impact of high gravity conditions during the hydrolysis and fermentation steps in an ethanol production process with wheat straw as the feedstock, at a very early development stage. Furthermore, the LCA was used to test the hypothesis that the production of second generation bio-ethanol at high gravity conditions is more environmentally friendly than at non-high gravity conditions. The results of the LCA are intended to help guide the development of the technology for high gravity hydrolysis and fermentation by providing technology developers, researchers and industry decision makers the environmental hotspots from an environmental life cycle point-of-view.

\section{Materials and methods}

\subsection{Description of the analyzed system}

A cradle-to-gate system, from the cultivation and harvesting of wheat straw (resource extraction) to the gate of the ethanol production plant, was defined for the analysis of a set of process configurations (see 2.2) (Fig. 1). The system was assumed to be situated in Kalundborg, Denmark.

It was assumed that enough straw is available nearby the plant and that it is cultivated and harvested at an average distance of $25 \mathrm{~km}$ from the plant. Also included in the upstream activities were the production of the enzymes, sodium hydroxide (needed to adjust the $\mathrm{pH}$ to 5.0) and polyethylene glycol (PEG), and the 
production of fuel and electricity that are needed in all parts of the studied system. The model of the production of ethanol and co-products was based on the IBUS process technology developed by Inbicon (Fig. 2) (Larsen et al., 2012). In this continuous process the wheat straw is first prepared and then hydrothermally pretreated. The pretreated straw is then washed to separate the solubilized hemicellulose from the fibres. The solubilized hemicellulose is concentrated and leaves the process as the by-product $\mathrm{C}_{5}$ molasses. Next, the pretreated fibres, now mainly consisting of cellulose and lignin, are enzymatically hydrolyzed and fermented to produce ethanol. During the downstream processing, ethanol is separated and purified up to $99.5 \%(\mathrm{v} / \mathrm{v})$ using distillation and molecular sieves, and the solids in the bottom product of the distillation are dried. These solids consist mainly of lignin and are made into lignin pellets. These pellets were assumed to provide the energy demands of the process, and were exported if a surplus was generated. It should be noted that the non-digested cellulose was treated as a material loss (it is neither recycled nor incinerated). This was done in order to produce lignin pellets by-product with a high purity. The distribution of the produced ethanol to the pump and the use phase was excluded from the assessment because the focus is on the development of the new high gravity technology for ethanol production.

\subsection{Set-up of the LCA}

The LCA was based on the results of a set of 33 laboratory experiments in which the key process variables (dry matter content, enzyme preparation and load, and process strategy) were varied. The rationale of the design of these experiments was to compare how the performance of the process (i.e. final ethanol yield) is affected by the introduction of novel commercial enzyme preparations. The two preparations that were compared were the novel Cellic CTec2 product and its predecessor, a 5:1 (weight) mix of Celluclast and Novozym 188 (henceforth called Celluclast), all from Novozymes A/S. The experimental design further involved:

- testing the influence of dry matter content (DM) of the process. Previous studies have shown that initial dry matter content has a significant impact on the process performance. The design involved testing two conditions, 20 and 30\% DM, which both are high dry matter conditions compared to most other studies, but cover the range which is regarded as industrially relevant.

- running the experiments at 30\% DM with the addition of polyethylene glycol (PEG, with an average molecular weight of 3000), with the goal to further increase the yield. It was expected that PEG addition would increase the yield because it lowers the interaction between lignin and enzyme, thereby reducing non-productive binding of the enzyme (Cannella and Jørgensen, 2014).

- testing two different enzyme loads. Enzyme load is an important process variable that determines the commercial feasibility of cellulosic ethanol production. The loads of the two enzyme preparations were 
5 and 7.5 FPU/g DM in order to compare the impact of enzyme load on the yield. These are reasonable loads from an industrial perspective.

- testing the two common process strategies applied in ethanol production from lignocellulose, separate hydrolysis and fermentation (SHF) and simultaneous saccharification and fermentation (SSF), along with the hybrid pre-saccharification and simultaneous fermentation (PSSF) strategy.

For a more detailed description of these experiments and their results, see Cannella and Jørgensen (2014). Additionally, for the sake of the LCA, a base case process configuration was defined for comparison purposes and lab experiments were run for it. In this configuration, the hydrolysis and fermentation were run at a more conventional dry matter content of $10 \%$, while the enzyme preparation used was Cellic CTec 2 at a load of 7.5 FPU/g DM. All three process strategies (SHF, PSSF, SSF) were tested.

The functional unit in this assessment was 1 liter of ethanol produced from wheat straw by a process system that uses the high gravity hydrolysis and fermentation technology. An attributional approach was followed to carry out this LCA, because the purpose was to identify improvement possibilities in the technologies in development (and to compare those to a defined base case), and thus on what to focus in the development. The life cycle impact assessment (LCIA) was carried out using the CML characterization method (Guinée et al., 2002). The following impact categories were selected for the evaluation of the high gravity process configurations:

- climate change/global warming potential (GWP)

The main goal of the use of biofuels is to reduce the use of fossil-based fuels and thus reducing their potential impact on global warming. In this assessment, biogenic greenhouse gas (GHG) emissions were assumed to be climate neutral, and thus only the environmental impact of fossil GHG emissions of the analyzed system were taken into account.

- eutrophication potential (EP)

The use of fertilizers during the cultivation of wheat can lead to increased eutrophication due to the emission of phosphorus and nitrogen.

- acidification potential (AP)

Combustion of fossil fuels and lignin pellets can lead to increased acidification due to the emission of $\mathrm{SO}_{2}, \mathrm{NH}_{3}$ and $\mathrm{NO}_{\mathrm{x}}$.

- photochemical ozone creation potential (POCP)

Combustion of fossil fuels and lignin pellets can lead to increased photochemical ozone creation due to the emission of volatile organic compounds (VOCs), $\mathrm{CO}$ and $\mathrm{NO}_{\mathrm{x}}$. 
As part of the assessment, an energy analysis of the product system was also carried out in order to assess energy use, both renewable (REU) and non-renewable (NREU). For the energy analysis, the ecoinvent cumulative energy demand method was used (Frischknecht et al., 2007). The environmental impact of the ethanol production may change significantly, for instance if the electricity fuel mix is (partly) based on renewable energy or if the energy needed in the production of the biofuel can be delivered by renewable resources. Sensitivity analyses were carried out to investigate changes in environmental impacts due to potential enzyme recycling (Fig. 2) and due to changes in the Danish energy mix over time.

A partitioning of the environmental burden based on the economic value of the main product (ethanol) and the by-products ( $\mathrm{C}_{5}$ molasses, lignin) was used (see Table 1) (Tillman, 2000). This was done according to the flow diagram of the Inbicon process includes two allocation points: one (allocation point A in Fig. 2) at the separation and wash stage where the $\mathrm{C}_{5}$ molasses is separated from the fibres, and one (allocation point $\mathrm{B}$ in Fig. 2) where the ethanol and lignin pellets are separated from the remaining liquid. In the case of allocation point $\mathrm{A}$, it was assumed that the price of the fibre flow out of the separation and wash stage was $50 € /$ tonne. Furthermore, straw is a by-product of wheat cultivation, which requires a partitioning of the environmental burden. Therefore, a third allocation point is at the wheat cultivation and harvesting process (allocation point $\mathrm{C}$ in Fig. 2). The ecoinvent process that is used used to model this process, 'wheat straw IP, at farm', already allocated this burden based on the straw's economic value: $7.5 \%$ of the environmental burden of the wheat cultivation and harvesting is allocated to the straw production (Nemecek and Kägi, 2007). A sensitivity analysis was carried out to investigate changes in the environmental impact allocated to ethanol due to varying product prices. In another analysis, the influence of applying system enlargement instead of economic allocation was investigated. When applying system enlargement, allocation is avoided, and the system under study is credited with the avoided emissions had its by-products been produced by an alternative process. In this analysis it was assumed that the lignin by-product is used to produce heat and replaced the production of an equivalent amount of heat from coal, and that the $\mathrm{C}_{5}$ molasses replaced the production of molasses from sugar beet. The ecoinvent processes 'heat, at hard coal industrial furnace 1-10MW' and 'molasses, from sugar beet, at sugar refinery' (Nemecek and Kägi, 2007) were used to model these alternative processes, respectively.

\subsection{Mass and energy balances and other data sources}

The mass and energy balances for the process configurations (the foreground system, see Figs. 1 and 2) were calculated based on the results of the lab experiments (see section 2.2), using a spreadsheet model. The main result of the experiments that tested the process configurations was the final ethanol yield after 168 hours, expressed as a percentage of the maximum theoretical ethanol yield (Cannella and Jørgensen, 2014). 
Furthermore, data on the usage of chemicals and enzyme in the experiments were gathered. It was assumed that these experimental lab data also apply to the industrial scale, i.e. the same yields and usage of enzyme and chemicals are assumed to apply. Next, the system was modeled at an industrial scale.

The yield was used to calculate the amount of ethanol produced based on the amount of cellulose available. Several assumptions were made as well in order to calculate the mass and energy flows in the foreground system. With regards to the resource extraction, and production of auxiliary material and energy: 1) the material loss from the field until the wheat straw is prepared to enter the pretreatment process was $15 \%$. This includes losses due to transportation, storage and preparation (Hurter, 2007); and 2) the water content of the harvested straw was $8 \%$. With regards to the ethanol production process: 1) the hydrothermal pretreatment of the straw took place at $\mathrm{p}=15$ bar and $\mathrm{T}=195^{\circ} \mathrm{C}$ with a residence time of 18.5 minutes; 2) the pretreated straw consisted of $55 \%(\mathrm{~m} / \mathrm{m})$ cellulose, $34 \%(\mathrm{~m} / \mathrm{m})$ lignin and $11 \%(\mathrm{~m} / \mathrm{m})$ other solid material; 3$)$ the heat input for distillation was taken from Galbe et al. (2007) (see p. 319, Fig. 6); 4) the solids after distillation (Fig. 2) were assumed to be dried by pressing up to a dry matter content of $50 \%$. These solids were then further dried up to $90 \% \mathrm{DM}$; and 5) it was assumed that lignin is burned with a $75 \%$ efficiency and the additional fossil fuel mix, if needed in the process configuration, with a $90 \%$ efficiency. The combustion of the lignin pellets was modeled using the 'Combustion, dry wood residue, AP-42' process from the US LCI database (NREL, 2012). This process was adjusted in order to account for the heating value of lignin (assumed to be $24 \mathrm{MJ} / \mathrm{kg}$ ) and the combustion efficiency of lignin. The additional fossil fuel mix was assumed to be the Danish energy fossil fuel mix (Danish Energy Agency, 2011).

Besides the assumptions used and modeling choices made to calculate the mass and energy balances for the foreground system, several choices had to be made for modeling the background system (Fig. 1):

1) the cultivation and harvesting of the straw was modeled using the ecoinvent process 'wheat straw IP, at farm' (Nemecek and Kägi, 2007)). This model assumes that $25 \%$ of the harvestable straw is left in the field, and this is accounted for in the allocation (see section 2.2).

2) the production of $\mathrm{NaOH}$ was modeled using the ecoinvent process 'sodium hydroxide, $50 \%$ in $\mathrm{H}_{2} \mathrm{O}$, production mix, at plant'. The environmental impact of this process is allocated according to the masses of the different products $\left(52.3 \% \mathrm{NaOH}, 46.4 \% \mathrm{Cl}_{2}\right.$ and $\left.1.3 \% \mathrm{H}_{2}\right)$. Mass allocation was applied in this process because the amounts produced of the three chemicals can be clearly determined (Althaus et al., 2007). $7 \mathrm{~g} \mathrm{NaOH} / \mathrm{kg} \mathrm{DM}$ of pretreated wheat straw was added in the experiments in order to adjust the $\mathrm{pH}$ to a level that is favorable to the hydrolysis and fermentation of the pretreated wheat straw.

3) the production of the Cellic CTec2 enzyme preparation was modeled using the life cycle inventory data 
published by Liptow et al. (2013) (see p. 1077, Table 5). In the case of a load of 5 FPU/g DM of pretreated wheat straw, this was equal to $50 \mathrm{~g}$ enzyme preparation $/ \mathrm{kg}$ DM of pretreated wheat straw. In the case of a load of $7.5 \mathrm{FPU} / \mathrm{g} \mathrm{DM}$ of pretreated wheat straw, this was equal to $75 \mathrm{~g}$ enzyme preparation/kg DM of pretreated wheat straw.

4) the production of the Celluclast/Novozym 188 enzyme preparation was modeled by considering the production of Celluclast for both types of enzyme in this mix. It was modeled using the 'Enzyme, Cellulase, Novozyme Celluclast' process from the US LCI database (NREL, 2012). In the case of a load of $5 \mathrm{FPU} / \mathrm{g} \mathrm{DM}$ of pretreated wheat straw, this was equal to $78 \mathrm{~g}$ enzyme preparation $/ \mathrm{kg} \mathrm{DM}$ of pretreated wheat straw. In the case of a load of 7.5 FPU/g DM of pretreated wheat straw, this was equal to $103 \mathrm{~g}$ enzyme preparation/kg DM of pretreated wheat straw.

5) the production of polyethylene glycol (PEG, average molecular weight of $3000 \mathrm{~g} / \mathrm{mol}$ ) was modeled by assuming it was produced from ethylene oxide via its interaction with water. The ecoinvent process 'ethylene oxide, at plant' was used to model this process (assuming that the impact of the polymerization of ethylene oxide to PEG is negligible) (Althaus et al., 2007). $10 \mathrm{~g}$ PEG/kg DM of pretreated wheat straw was added in the experiments that used PEG.

6) the fossil fuel mix used as additional fuel for the ethanol production process was assumed to be the Danish mix from 2009 and consists of 29\% coal, 50\% oil and 21\% natural gas (Danish Energy Agency, 2011). This fuel is used for steam production. Changes in the fossil fuel mix over time were taken into account using sensitivity analysis.

7) the electricity used by the ethanol production process was produced in Denmark, and was modeled with the ecoinvent process 'electricity mix (DK)'.

The LCA software openLCA version 1.3 was used to model the complete ethanol production systems according to Fig. 1 (both the foreground and background systems) for the different process configurations, and to calculate their environmental impacts. The mass and energy balance results for the process configurations and the models used for describing the background system were thus integrated in this software.

\section{Results and discussion}

All process configurations run at high dry matter content (20 and 30\% DM, respectively) and the base case configurations (at $10 \% \mathrm{DM}$ ) were analyzed in order to determine their environmental impact and energy use. The results are summarized in Fig. 3. This figure depicts the results for the four environmental impact categories analyzed, at the two different dry matter contents at which experiments were carried out and with 
the two different enzyme preparations. Furthermore, the experiments at 30\% DM content with an addition of PEG are shown in their own separate bar charts. Each bar chart contains the results for the different process strategies at the two different enzyme loads used and the base case experiments run at $10 \%$ DM. The yields of all experiments are shown above the bars in the charts showing the global warming potentials (GWP), and it is also depicted to what extent different stages in the life cycle contribute to the result. It should be noted that the three base case experiments (run with SHF, PSSF and SSF process strategies) all resulted in the same yield, and consequently had the same environmental impact. Therefore, in Fig. 3 only one bar is shown to represent these experiments. Most of the results discussion will revolve around Fig. 3.

There is no simple answer to the question whether high gravity hydrolysis and fermentation is environmentally preferable to hydrolysis and fermentation at the more conventional 10\% DM conditions (Fig. 3). It is however clear that the configurations running at 30\% DM without the addition of PEG are not preferable options. Furthermore, it is not directly obvious which process strategy (SSF, PSSF or SHF) is the better one. What can be seen at first glance is that the environmental impact is dominated by enzyme production, at all investigated process configurations and for both types of enzyme preparations. It is also clear that the acidification (AP) and photo-chemical ozone creation (POCP) potentials co-vary with the GWP. This is according to expectations because all these types of impacts are mostly a result of the significant use of non-renewable energy during the enzyme production and its resulting emissions of $\mathrm{CO}_{2}(\mathrm{GWP}), \mathrm{SO}_{2}(\mathrm{AP})$, and $\mathrm{NO}_{\mathrm{x}}$ and volatile organic compounds (POCP). Eutrophication potential (EP) on the other hand is caused by $\mathrm{NO}_{\mathrm{x}}$ emissions from combustion but also by leakage of fertilizers during the wheat cultivation phase.

In order to structure the analysis that follows, the causal diagrams depicted in Fig. 4 were constructed. Yield seems to be the factor which explains most of the results, and is hence given a central role in the diagrams. Yield is affected by the studied process variables, and yield consequently affects the non-renewable energy use (NREU) of the process configuration and its related emissions (Fig. 4a). Yield also affects wheat straw consumption (which consequently affects the renewable energy use (REU)) and hence eutrophication due to the cultivation of wheat (Fig. 4b). It should be noted that the 'process strategy' variable (see section 2.2) is not part of the constructed causal diagrams. When varying the process strategy (SHF, PSSF or SSF), keeping all other process variables constant, none of them is clearly preferable. Cannella and Jørgensen (2014) observed nevertheless that there is a difference in the preferred choice of process strategy between the two enzyme preparations (Cellic CTec2 or Celluclast) at 30\% DM when considering yield: the use of Cellic CTec2 resulted in a higher yield when using SHF or PSSF, whereas the use of Celluclast resulted in a higher yield when using SSF or PSSF. For a more in-depth discussion on the influence of the process strategy on the yield, see Cannella 
and Jørgensen (2014).

\subsection{Yield of process configuration}

The yield is the main determinant of the environmental impact of a configuration. Keeping all process variables constant (see section 2.2), except for the process strategy, all environmental impacts studied will decrease with an increasing yield (Fig. 3).

Also, the renewable and non-renewable energy use (REU and NREU, respectively) vary with the yield. This results in a decreasing trend of the total extracted energy, as defined by Arvidsson et al. (2012) and calculated here as the sum of REU and NREU. The yield of the process configurations has a significant influence on the REU which indicates that the amount of wheat straw needed varies widely among the tested process configurations (from $5.5 \mathrm{~kg}$ up to $18.6 \mathrm{~kg}$ for the production of 1 liter of ethanol). The NREU varies to a lesser extent with the yields (from $25 \mathrm{MJ}$ to $63 \mathrm{MJ}$ per liter of ethanol) when compared to the REU, and depends mostly on the amount of added enzyme and polyethylene glycol (PEG). These two process variables (see section 2.2) greatly affect the yield and therefore the REU. It can be stated that generally the REU (straw use) decreases with increased NREU (enzyme load and PEG addition), which is in accordance with the analysis based on the causal diagram for eutrophication potential (Fig. 4b).

The yield of the base case configurations (10\% DM, Cellic CTec2 at 7.5 FPU/g DM) is the highest of all configurations at $92 \%$ for each of the three process strategies tested (SHF, PSSF and SSF). However, for none of the impact categories does the base case configuration outperform all other configurations. This is explained by the use of additional fossil fuel by the base case configuration that is required for satisfying its energy demand (Figs. 3 and 5a). In other words, the energy contained in the lignin pellets produced by the base case configuration itself is not enough to meet its total energy needs which are higher because of its higher energy use during the distillation of the more dilute fermentation broth.

Of the process configurations running at high dry matter content (20 or 30\% DM), those with the highest and lowest yields are both run at 30\% DM. When comparing the base case configuration and the configuration with the highest yield (30\% DM, PEG addition, Cellic CTec2, 7.5 FPU, PSSF with a yield of 89\%) from an energy perspective, it becomes clear that these configurations differ due to the extra fossil fuel that is needed in the base case, and the addition of PEG and the small amount of lignin product in the highest yield configuration (Fig. 5b). When doing this comparison between the base case and the lowest yield configuration (30\% DM, Celluclast, 5 FPU, SHF with a yield of $27 \%$ ), the main difference is the renewable energy input needed to produce 11 of ethanol (Fig. 5c). The product flow that contains most energy is the hemi-cellulose that is used to produce the $\mathrm{C}_{5}$ molasses in the lowest yield configuration, whereas in the base case (and the highest 
yield configuration) this energy flow is similar to the energy contained in 11 of ethanol. As well, the energy contained in the lignin product is larger than in the highest yield configuration: $14 \%$ of the lignin that enters the downstream processing step leaves the system as lignin product, whereas in the highest yield configuration this is $3 \%$.

It should be noted that the non-digested cellulose was treated as a material loss (see 2.1). If this cellulose was burned, it would replace a part of the extra fossil fuel that is needed in the base case configurations (Fig. 5a). In the case of the lowest yield configuration (Fig. 5c), an excess of energy would be produced if this cellulose was burned (assuming a combustion efficiency of 75\%). This energy would then be another by-product of the process, and this would consequently change the environmental impact allocated to the ethanol that is produced.

\subsection{Enzyme load and preparation}

Another important determinant of the environmental impact of a configuration is the enzyme load. An increased enzyme load increases the yield for all process configurations (keeping all other process variables constant). However, this does not lead to a lower environmental impact: a higher enzyme load generally leads to higher global warming (GWP), acidification (AP) and photo-chemical ozone creation potentials (POCP) because of a higher non-renewable energy use (Fig. 4a). This is due to the large amount of fossil energy that is used during enzyme production (120 MJ and $52.1 \mathrm{MJ}$ per $\mathrm{kg}$ of Cellic CTec2 and Celluclast enzyme preparations, respectively). There are two exceptions to this generalization: 1) the configurations running at 30\% DM with PEG addition using Cellic CTec2 (Fig. 3c); and 2) the acidification potential of the configurations using Celluclast (Figs. $3 \mathrm{~d}$ and $3 \mathrm{e}$ ). In these cases, the impact of the increase in yield outweighs (or compensates) the impact of increased enzyme load and leads to a decreased (or equal) environmental impact. This demonstrates a trade-off between a reduced environmental impact due to increased yield, which is due to the increased enzyme load, and an increased environmental impact due to enzyme production. The causal link between enzyme load and eutrophication potential (EP) shows a different behavior (Fig. 4b). In this case, the impact of the increase in yield either compensates or, in some cases, outweighs the impact of increased enzyme load, thus leading to an equal or lower EP. Reasons for this different behavior are that 1) the enzyme production has a lower relative contribution to EP when compared to the other impact categories; and 2) the increased enzyme load leads to decreased straw use, which consequently leads to a lower contribution of straw cultivation and harvesting to EP (Fig. 3). There is one exception to this behavior, the configuration running at 30\% DM using Celluclast and the SHF process strategy (Fig. 3e), where the increase in yield is not great enough to compensate the impact of increased enzyme load. 
Changing the type of enzyme preparation, from the Cellic CTec2 preparation to the Celluclast preparation, lowers the yield of all process configurations (keeping all other process variables constant). However, this does in general not lead to a higher GWP, AP and POCP (Fig. 4a). This is due to the lower fossil energy use during the Celluclast production when compared to the Cellic CTec2 production. The configurations running at an enzyme load of 5 and 7.5 FPU/g DM, both at 30\% DM and using the SHF process strategy are two notable exceptions to this generalization. For these configurations all environmental impacts are higher because the decrease in yield is too great for the lower fossil energy use for Celluclast production to compensate. In the case of eutrophication potential, the causal links are the same as for the enzyme load (Fig. 4b).

\subsection{Dry matter content and PEG addition}

The dry matter content has a direct influence on the yield of a configuration: the higher the dry matter content, the lower the yield which consequently leads to a higher energy use (both REU and NREU) and thus to a higher environmental impact (keeping all other process variables equal) (Figs. 3 and 4). The addition of polyethylene glycol (PEG) has a direct positive influence on the yield and thus on the total energy use and the environmental impact of a configuration (compare Figs. 3b and 3c).

It should be noted that the production of PEG contributes little to all impact categories (Figs. 3c and 3f). The expected increase in the yield due to PEG addition is thus achieved without causing a significant environmental burden due to PEG production which is fossil-based. This is due to the small amount of PEG, $10 \mathrm{~g}$ per $\mathrm{kg}$ of dry matter, that was added to the experiments at 30\% DM (Cannella and Jørgensen, 2014).

\subsection{Sensitivity and uncertainty analyses}

\subsubsection{Mass and energy balances}

The additional use of fossil fuel by the base case configuration depends on the combustion efficiency of the fossil fuel and lignin combustion (assumed to be $90 \%$ and $75 \%$, respectively). For instance, if the lignin combustion efficiency could be increased to $87 \%$, then the base case configuration would not need additional fossil fuel. Avoiding additional fossil fuel use could also be achieved by increasing the energy efficiency of the pretreatment process step which needs a significant amount of energy (Fig. 5a). In this case, the pretreatment would need to be $29 \%$ more energy efficient in order to avoid additional fuel use in the base case configuration. These measures would lead to a reduction of approximately $14 \%$ of the GWP of the base case configuration. Such efficiency improvements would also change the environmental impact of the ethanol produced with the process configurations run at higher dry matter content. For instance, increasing the lignin combustion efficiency of the high gravity process configuration with the highest yield (Fig. 5b) to 87\% would lead to an 
increase in the amount of lignin by-product from $0.74 \mathrm{MJ}$ to $4.3 \mathrm{MJ}$. Consequently, the GWP allocated to the produced ethanol would decrease by approx. $8 \%$. For the high gravity process configuration with the lowest yield (Fig. 5c) the amount of lignin by-product would increase from 13.6 MJ to 23.6 MJ, and reduce the GWP allocated to ethanol by approx. $15 \%$.

\subsubsection{Allocation choices and system enlargement}

The impact results do not show a large sensitivity due to changes in the price of ethanol (allocation point B) or the pretreated fibre stream (allocation point A) (Fig. 2). Increasing the ethanol price from $600 € /$ tonne to $825 € /$ tonne results in an increase of 0 to $6.5 \%$ in the impact results. Increasing the price of the pretreated fibre stream from $50 € /$ tonne to $86 € /$ tonne results in an increase of 0.4 to $10 \%$ in the impact results. The configurations with the lowest yields show the greatest sensitivity.

Wheat straw may be considered as a waste product. This implies that the environmental burdens of the cultivation and harvesting operations (see Fig. 1) are all allocated to the production of the wheat grain because the straw will have no economic value under such a consideration. In the case of GWP, AP and POCP, this leads to a reduction of the environmental impact of 11 to $22 \%, 12$ to $23 \%$ and 2 to $4 \%$, respectively. In the case of EP, the reduction is more significant and is 43 to $52 \%$ (see also Fig. 3). The configurations using the Celluclast enzyme cocktail show the greatest sensitivity.

System enlargement leads to different results for the environmental impact of a process configuration. To illustrate this, system enlargement was applied to the process configurations that are depicted in Fig. 5, and the results are shown in Fig. 6. The results show that, especially in the case of the process configurations with a lower yield, the amounts of the by-products that are produced have a significant influence on the environmental impact of a process configuration. However, for these three process configurations, the numerical results for GWP, AP and POCP are similar to those when applying economic allocation. The numerical results for EP show a larger discrepancy, where applying system enlargement results in a higher impact. It should be noted that these results strongly depend on the choice of alternative processes for the production of $\mathrm{C}_{5}$ molasses and heat produced by lignin combustion when modeling the system enlargement.

\subsubsection{Biogenic greenhouse gas emissions}

As stated in section 2.2, the impact that is caused by emissions of biogenic greenhouse gases (GHGs) was not included in the assessment. Hence, the benefits from $\mathrm{CO}_{2}$ uptake during growth were not included either. However, had this been done it would change the results for the GWP of the analyzed process configurations to a certain extent. What follows is a short discussion of where the main biogenic GHG emissions occur in the 
analyzed system from a cradle-to-gate and a cradle-to-grave perspective, and how the impact of these would manifest themselves.

From a cradle-to-gate perspective, biogenic $\mathrm{CO}_{2}$ emission takes place during the fermentation: for every liter of ethanol that is produced from a $\mathrm{C}_{6}$ sugar via fermentation, $0.75 \mathrm{~kg}$ of $\mathrm{CO}_{2}$ is produced. Furthermore, biogenic $\mathrm{CO}_{2}$ is emitted when burning lignin pellets to meet the process energy demands (approx. $0.1 \mathrm{~kg} \mathrm{CO}_{2}$ per $\mathrm{MJ}$ produced (AEA Technology, 2012)). When applying a cradle-to-grave perspective, by, for instance, using the produced ethanol as a transportation fuel and the $\mathrm{C}_{5}$ molasses in cow feed production, biogenic $\mathrm{CO}_{2}$ is also emitted during the combustion of the ethanol (1.5 $\mathrm{kg}$ of $\mathrm{CO}_{2}$ per liter of ethanol, assuming perfect combustion), and emissions of biogenic $\mathrm{CH}_{4}$ occur after consumption and digestion by cows of feed containing the $\mathrm{C}_{5}$ molasses due to enteric fermentation (approx. $21 \mathrm{~g} \mathrm{CH}_{4}$ per $\mathrm{kg}$ of dry matter feed intake (Flysjö et al., 2011); $\mathrm{C}_{5}$ molasses makes up a small percentage of this dry matter feed). Furthermore, excess lignin pellets that are produced and exported may be burned and thus emit biogenic $\mathrm{CO}_{2}$. All these emissions take place not long after the straw has been harvested.

The GWP of all these emissions is counteracted by the uptake of $\mathrm{CO}_{2}$ due to the growth of wheat. Nevertheless, a certain amount of radiative forcing due to these emissions will occur because this uptake is not instantaneous. Therefore, incorporating the impact of biogenic $\mathrm{CO}_{2}$ in the assessment would increase the GWP for all process configurations from both the cradle-to-gate and cradle-to-grave perspective. However, this will only be a marginal increase due to the fast growth rate of wheat when compared to, for instance, trees (Liptow et al. (2014), unpublished results). It should be noted that the impact of biogenic GHGs depends on the end-of-life stage of the ethanol and the by-products. For instance, if the produced ethanol were used as a precursor for bio-polyethylene (bio-PE) production, the carbon may be sequestered for a longer time compared to using ethanol as a transportation fuel, depending on what type of product the bio-PE is applied in. Furthermore, the methods used to assess the impact of biogenic greenhouse gas emissions are still in development, and may currently introduce additional uncertainty in the assessment results.

\subsubsection{Enzyme recycling}

Because of the significant influence of the enzyme production and use, an analysis was done of the situation in which $25 \%$ of the activity of the enzyme is recycled. This value was chosen after consulting with an industrial project partner if this would be a feasible target. This was done for the base case configurations, and for the configurations running at high dry matter content with the highest and lowest yields. The analysis shows that improvements can be made in the environmental impact of the process configurations due to a reduction of the use of fresh enzyme preparation (Table 2). Other work already showed that an increase of enzyme activity 
will also improve the environmental impact of the process in which the enzyme is used (Liptow et al., 2013).

\subsubsection{Changes in energy mix}

The influence of the anticipated share of fossil fuel in the Danish energy mix over time (Lund and Mathiesen, 2009; Danish Energy Agency, 2011) on the GWP of the enzyme production, and of the fossil fuel use for process energy, was analyzed. This was done for the base case configuration, and for the configurations running at high dry matter content with the highest and lowest yields (Table 3). The fossil fuel mix itself is also projected to change over time (largely replacing coal with natural gas, but maintaining oil use) and this was also taken into account. The results show that the total GWP of the configurations significantly decreases. Furthermore, the impact of the use of fossil fuel for process energy in the base case configuration does not change drastically (13\%), while the impact of enzyme production decreases significantly (ca. 40\%) (not shown in Table 3). Combining this result with the result of enzyme recycling (see section 3.4.4) indicates that the environmental impact of the process configurations can be improved significantly by having a more efficient enzyme use and a cleaner enzyme production.

\subsection{Comparison with other relevant studies}

The environmental impact of the tested process configurations were compared with those published in two other studies (Wang et al., 2013; Borrion et al., 2012). These studies were chosen because they also evaluated bioethanol production from wheat straw. Both studies were based on a plant design with a capacity of 2000 metric tonnes per day of wheat straw, whereas the current study used raw lab data to perform the LCA of the experimental process configurations without scale-up considerations. It should be noted that no other studies were found that evaluated the influence of high gravity conditions on the environmental impact of second generation bioethanol production.

Wang et al. (2013) studied the environmental sustainability of bioethanol production from wheat straw in the UK using, among others, liquid hot water pretreatment. This study was set up as a 'well-to-wheel' LCA and the functional unit was 'to drive $1 \mathrm{~km}$ in a flexible-fuel vehicle'. The ethanol production process was based on the NREL corn stover-to-ethanol model (Humbird et al., 2011). The enzyme preparation for hydrolysis was Cellic CTec at a loading of $10 \mathrm{FPU} / \mathrm{g}$ glucan (approx. 3.3 FPU/g DM). The fermentation process was carried out using Zymomonas mobilis capable of fermenting both $\mathrm{C}_{5}$ and $\mathrm{C}_{6}$ monomer sugars. There was thus no $\mathrm{C}_{5}$ by-product stream. Instead, surplus electricity was the by-product which was credited with avoided emissions of average electricity generation. They found that enzyme production is a main contributor due to its energy-intensive nature. Furthermore, the ethanol production process (not including straw cultivation and harvesting) emitted 
$4.52 \mathrm{~kg} \mathrm{CO} 2$ per 1 ethanol. This however included biogenic $\mathrm{CO}_{2}$ emissions of approximately $2.8 \mathrm{~kg} / \mathrm{l}$ ethanol from burning the distillation bottom product (Wang et al. (2013), p. 721, Fig. 4b). Therefore, approximately 1.7 $\mathrm{kg} \mathrm{CO}_{2, \mathrm{eq}}$ per 1 ethanol were emitted, assuming climate neutrality of the biogenic carbon. This is comparable to the results for the base case and most of the process configurations running at 30\% DM with PEG addition (Figs. 3c and 3f), as well as most of the process configurations running at 20\% DM (Figs. 3a and 3d).

Borrion et al. (2012) did a LCA of bio-ethanol production from wheat straw and used an older version of the NREL corn stover-to-ethanol model (Aden et al., 2002) to describe the ethanol production process. The wheat straw was pretreated using dilute sulfuric acid hydrolysis. This study did not specify the enzyme preparation that was used. This was also a 'well-to-wheel' LCA and the functional unit was the amount of fuel needed to drive $1 \mathrm{~km}$ with a small passenger car. This study found a GWP of $3.3 \mathrm{~kg} \mathrm{CO}_{2, \mathrm{eq}}$ per 1 ethanol when considering

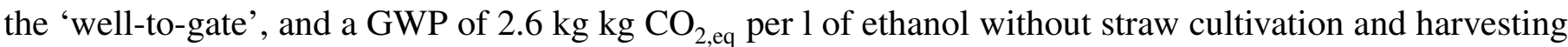
(Borrion et al. (2012), see p. 14, Table 5). Like Wang et al. (2013), this study also pointed out the significant contribution of the enzyme production. Furthermore, the global warming potential of the ethanol production (not including straw cultivation and harvesting) is comparable to or slightly higher than most of the process configurations run at 30\% DM (Figs. 3b and 3e).

\section{Conclusion}

Higher dry matter content leads to a higher environmental impact of ethanol production. Nevertheless, the results indicate that reduction of the impact of enzyme production and use, and the use of PEG at 30\% DM can compensate this increase. The results also show that the renewable and non-renewable energy use resulting from the different process configurations ultimately determine their environmental impact. Future development work may focus on determining the process conditions at which the environmental impact is minimized by finding the optimal dry matter content for the hydrolysis and fermentation, and decreased enzyme use while maintaining a high yield.

\section{Supplementary material}

Supplementary material is available as an electronic annex.

\section{Acknowledgements}

This study was funded by the Nordic Energy Top-level Research Initiative, project TFI PK-bio 02, "HG Biofuels". We thank the other project participants for fruitful discussions throughout this work. We also thank 
Eoin White and Tomasz Stec for contributing to building the LCA model including the system enlargement.

\section{References}

Aden, A., Ruth, M., Ibsen, K., Jechura, J., Neeves, K., Sheehan, J., Wallace, B., Montague, L., Slayton, A., Lukas, J., 2002. Lignocellulosic biomass to ethanol process design and economics utilizing co-current dilute acid prehydrolysis and enzymatic hydrolysis for corn stover. Research Report TP-510-32438, NREL. URL http://www.nrel.gov/docs/fy02osti/32438.pdf

AEA Technology, 2012. 2012 Guidelines to Defra / DECC's GHG Conversion Factors for Company Reporting. Tech. rep., Department of Energy and Climate Change (DECC) and the Department for Environment, Food and Rural Affairs (Defra).

URL https://www.gov.uk/government/uploads/system/uploads/attachment_data/file/69568/ pb13792-emission-factor-methodology-paper-120706.pdf

Althaus, H.-J., Chudacoff, M., Hischier, R., Jungbluth, N., Osses, M., Primas, A., 2007. Life cycle inventories of chemicals. Tech. Rep. ecoinvent report No. 8, EMPA Dübendorf.

URL http://db.ecoinvent.org/reports/08_Chemicals.pdf

Arvidsson, R., Fransson, K., Fröling, M., Svanström, M., Molander, S., 2012. Energy use indicators in energy and life cycle assessments of biofuels: review and recommendations. J. Clean. Prod. 31, 54-61.

Bentsen, N., Felby, C., 2012. Biomass for energy in the European Union - a review of bioenergy resource assessments. Biotechnol. Biofuels 5, 25.

Borrion, A. L., McManus, M. C., Hammond, G. P., 2012. Environmental life cycle assessment of bioethanol production from wheat straw. Biomass Bioenerg. 47, 9-19.

Cannella, D., Hsieh, C. C., Felby, C., Jørgensen, H., 2012. Production and effect of aldonic acids during enzymatic hydrolysis of lignocellulose at high dry matter content. Biotechnol. Biofuels 5, 26.

Cannella, D., Jørgensen, H., 2014. Do new cellulolytic enzyme preparations affect the industrial strategies for high solids lignocellulosic ethanol production? Biotechnol. Bioeng. 111, 59-68.

Cherubini, F., Strømman, A. H., 2011. Life cycle assessment of bioenergy systems: State of the art and future challenges. Bioresource Technol. 102, 437-451. 
Cherubini, F., Ulgiati, S., 2010. Crop residues as raw materials for biorefinery systems - A LCA case study. Appl. Energ. 87, 47-57.

Danish Energy Agency, 2011. Energy strategy 2050 - from coal, oil and gas to green energy. Tech. rep., Danish Energy Agency.

URL http://www.ens.dk/sites/ens.dk/files/dokumenter/publikationer/downloads/energy_strategy_2050.pdf

Ekman, A., Wallberg, O., Joelsson, E., Börjesson, P., 2013. Possibilities for sustainable biorefineries based on agricultural residues - A case study of potential straw-based ethanol production in Sweden. Appl. Energ. 102, 299-308.

Flysjö, A., Henriksson, M., Cederberg, C., Ledgard, S., Englund, J.-E., 2011. The impact of various parameters on the carbon footprint of milk production in New Zealand and Sweden. Agr. Syst. 104, 459-469.

Frischknecht, R., Jungbluth, N., Althaus, H.-J., Bauer, C., Doka, G., Dones, R., Hischier, R., Hellweg, S., Humbert, S., Köllner, T., Loerincik, Y., Margni, M., Nemecek, T., 2007. Implementation of life cycle impact assessment methods. Tech. Rep. ecoinvent report No. 3, Swiss Centre for Life Cycle Inventories.

URL http://www.ecoinvent.org/fileadmin/documents/en/03_LCIA-Implementation.pdf

Galbe, M., Sassner, P., Wingren, A., Zacchi, G., 2007. Process engineering economics of bioethanol production. In: Olsson, L. (Ed.), Biofuels. Vol. 108 of Advances in Biochemical Engineering/Biotechnology. Springer Berlin Heidelberg, pp. 303-327.

Guinée, J., Gorrée, M., Heijungs, R., Huppes, G., Kleijn, R., de Koning, A., van Oers, L., Wegener Sleeswijk, A., Suh, S., Udo de Haes, H., de Bruijn, H., van Duin, R., Huijbregts, M., 2002. Handbook on life cycle assessment. Operational guide to the ISO standards. Kluwer Academic Publishers, Dordrecht.

Hillman, K. M., Sandén, B. A., 2008. Time and scale in Life Cycle Assessment: the case of fuel choice in the transport sector. Int. J. Alternative Propulsion 2, 1-12.

Humbird, D., Davis, R., Tao, L., Kinchin, C., Hsu, D., Aden, A., Schoen, P., Lukas, J., Olthof, B., Worley, M., Sexton, D., Dudgeon, D., 2011. Process design and economics for biochemical conversion of lignocellulosic biomass to ethanol - dilute-acid pretreatment and enzymatic hydrolysis of corn stover. Tech. Rep. NREL/TP5100-47764, NREL.

URL http://www.nrel.gov/docs/fy11osti/47764.pdf 
Hurter, R. W., 2007. Nonwood fiber raw materials and the biorefinery. In: 2007 TAPPI Engineering, Pulping \& Environmental Conference.

International Organization of Standardization, 2006. Environmental management - Life cycle assessment Principles and framework (ISO 14040).

Jørgensen, H., Kristensen, J. B., Felby, C., 2007. Enzymatic conversion of lignocellulose into fermentable sugars: challenges and opportunities. Biofuel. Bioprod. Bior. 1, 119-134.

Koppram, R., Tomás-Pejó, E., Xiros, C., Olsson, L., 2014. Lignocellulosic ethanol production at high-gravity: challenges and perspectives. Trends Biotechnol. 32, 46-53.

Larsen, J., Østergaard Haven, M., Thirup, L., 2012. Inbicon makes lignocellulosic ethanol a commercial reality. Biomass Bioenerg. 46, 36-45.

Liptow, C., Tillman, A.-M., 2012. A Comparative Life Cycle Assessment Study of Polyethylene Based on Sugarcane and Crude Oil. J. Ind. Ecol. 16, 420-435.

Liptow, C., Tillman, A.-M., Janssen, M., Wallberg, O., Taylor, G., 2013. Ethylene based on woody biomass: what are environmental key issues of a possible future swedish production on industrial scale. Int. J. Life Cycle Ass. 18, 1071-1081.

Lund, H., Mathiesen, B., 2009. Energy system analysis of 100\% renewable energy systems - The case of Denmark in years 2030 and 2050. Energy 34, 524-531.

Morgen, C., 2006. Integrated biomass utilisation system. Tech. Rep. no. 486762, DONG Energy.

URL http://www.biorefinery-euroview.eu/biorefinery/private/documents/Integrated\%20Biomass\% 20Utilisation\%20System.pdf

Nemecek, T., Kägi, T., 2007. Life cycle inventories of agricultural production systems. Tech. Rep. ecoinvent report No. 15, Agrosope Reckenholz-Tänikon Research Station ART.

URL http://db.ecoinvent.org/reports/15_Agriculture.pdf

NREL, 2012. U.S. life cycle inventory database. Accessed April 2013.

URL https://www.lcacommons.gov/nrel/search

Puligundla, P., Smogrovicova, D., Obulam, V., Ko, S., 2011. Very high gravity (VHG) ethanolic brewing and fermentation: a research update. J. Ind. Microbiol. Biot. 38, 1133-1144. 
Qin, C., 2009. Lignin as alternative renewable fuel.

URL http://www.altenergymag.com/emagazine/2009/06/lignin-as-alternative-renewable-fuel/1384

Shibasaki, M., Albrecht, S., Kupfer, T., 2007. Small scale and large scale plants - effect on life cycle assessment. In: $17^{\text {th }}$ European Symposium on Computer Aided Process Engineering - ESCAPE17. p. 6.

Skøtt, T., 2011. Straw to Energy. Status, Technologies and Innovation in Denmark 2011. Tech. rep., INBIOM. URL http://www.inbiom.dk/download/viden_biomasse/halmpjeceuk_2011.pdf

Tillman, A.-M., 2000. Significance of decision-making for LCA methodology. Environ. Impact Assess. 20, $113-123$.

Wang, L., Littlewood, J., Murphy, R. J., 2013. Environmental sustainability of bioethanol production from wheat straw in the UK. Renew. Sust. Energ. Rev. 28, 715-725. 


\section{Table captions}

\section{Table 1}

Energy content and price for the feedstock (wheat straw) and the products (ethanol, $\mathrm{C}_{5}$ molasses and lignin) of the process

\section{Table 2}

Reduction in the environmental impacts due to enzyme recycling for the: a. base case (10\% DM, 7.5 FPU, all process strategies, yield $=92 \%)$; b. high gravity process configuration with the highest yield (30\% DM, PEG addition, Cellic CTec2, 7.5 FPU, PSSF, yield = 89\%); c. high gravity process configuration with the lowest yield (30\% DM, Celluclast, 5 FPU, SHF, yield $=27 \%$ ).

\section{Table 3}

Global warming potentials (GWP) (in $\mathrm{kg} \mathrm{CO}_{2, \text { eq }}$ per liter of ethanol produced) due to projected changes in the Danish energy mix for the: a. base case (10\% DM, 7.5 FPU, all process strategies, yield $=92 \%)$; b. high gravity process configuration with the highest yield (30\% DM, PEG addition, Cellic CTec2, 7.5 FPU, PSSF, yield = 89\%); c. high gravity process configuration with the lowest yield (30\% DM, Celluclast, 5 FPU, SHF, yield $=27 \%)$. 


\section{Figure captions}

Fig. 1. Cradle-to-gate system for the evaluation of the high gravity process configurations. The parts of the flow chart with the dashed lines have not been included in the assessment.

Fig. 2. Flow diagram of the Inbicon process (adjusted from Larsen et al. (2012)). In bold, the products are indicated; in italics, several flows are specified. Three allocation points applied in the LCA are indicated.

Fig. 3. Life cycle impact assessment results for the process and the base case configurations. Figs. 3a to $3 \mathrm{c}$ show the results for the Cellic CTec2 enzyme preparations; Figs. 3d to 3f show the results for the Celluclast enzyme preparations. The numbers above the bars in the GWP charts are the ethanol yields of the configurations.

Fig. 4. Effects of the process variables on: a. global warming potential (GWP), acidification potential (AP) and photo-chemical ozone creation potential (POCP); b. eutrophication potential (EP). A '+'-sign declares a positive causal link, e.g. if the enzyme load increases, then the yield increases. A '-'-sign declares a negative causal link, e.g. if DM content increases, then yield decreases. In red, the main differences between the diagrams are indicated.

Fig. 5. Sankey diagrams of the energy flows in the: a. base case (yield $=92 \%)(10 \% \mathrm{DM}, 7.5 \mathrm{FPU}$, all process strategies); b. high gravity process configuration with the highest yield (yield $=89 \%)(30 \% \mathrm{DM}$, PEG addition, Cellic CTec2, 7.5 FPU, PSSF); c. high gravity process configuration with the lowest yield (yield $=27 \%)(30 \% \mathrm{DM}$, Celluclast, 5 FPU, SHF). The flows through the main process, and the amounts of renewable and non-renewable fuel used are distinguished.

Fig. 6. Results of the LCA when applying system enlargement for the: a. base case (10\% DM, 7.5 FPU, all process strategies); b. high gravity process configuration with the highest yield (30\% DM, PEG addition, Cellic CTec2, 7.5 FPU, PSSF); c. high gravity process configuration with the lowest yield (30\% DM, Celluclast, 5 FPU, SHF). 


\section{Tables}

Table 1

\begin{tabular}{lcc}
\hline & Energy content $[\mathrm{MJ} / \mathrm{kg}]$ & Price [€/tonne] \\
\hline Wheat straw & 17.2 & $40^{1}$ \\
Ethanol & 29.7 & $600^{2}$ \\
Lignin & 24 & $300^{3}$ \\
$\mathrm{C}_{5}$ molasses & 18 & $86^{4}$ \\
\hline
\end{tabular}

${ }^{1}$ Price of wheat straw fluctuates significantly; $€ 40$ per delivered tonne is assumed (Ekman et al., 2013).

2 http://www.nasdaq.com/markets/ethanol.aspx

${ }^{3}$ Assumed to be sold as an alternative renewable fuel (Qin, 2009).

${ }^{4}$ See Morgen (2006). 
Table 2

Reduction of environmental impacts

\begin{tabular}{lcccc} 
Process configuration & GWP & EP & AP & POCP \\
\hline Base case & $18 \%$ & $11 \%$ & $15 \%$ & $23 \%$ \\
Highest yield & $21 \%$ & $12 \%$ & $17 \%$ & $24 \%$ \\
Lowest yield & $18 \%$ & $9 \%$ & $9 \%$ & $23 \%$ \\
\hline
\end{tabular}


Table 3

Fossil share in energy mix

\begin{tabular}{llcc} 
& $80 \%$ & $67 \%$ & $50 \%$ \\
\hline Process configuration & GWP $\left[\mathrm{kg} \mathrm{CO}_{2, \mathrm{eq}} / \mathrm{l}\right.$ of ethanol $]$ \\
\hline Base case & 2.6 & 2.3 & 1.7 \\
Highest yield & 2.3 & 2.0 & 1.5 \\
Lowest yield & 3.1 & 2.6 & 2.0 \\
\hline
\end{tabular}




\section{Figures}

Figure 1

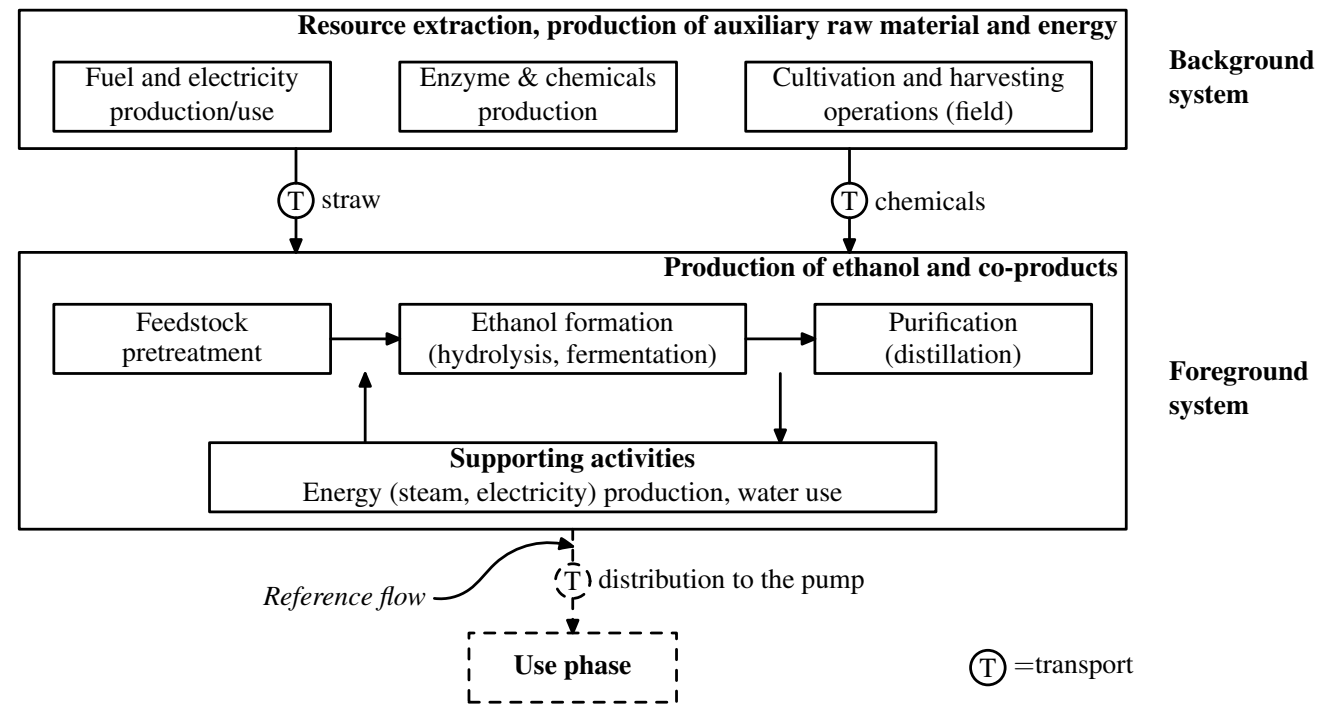


Figure 2

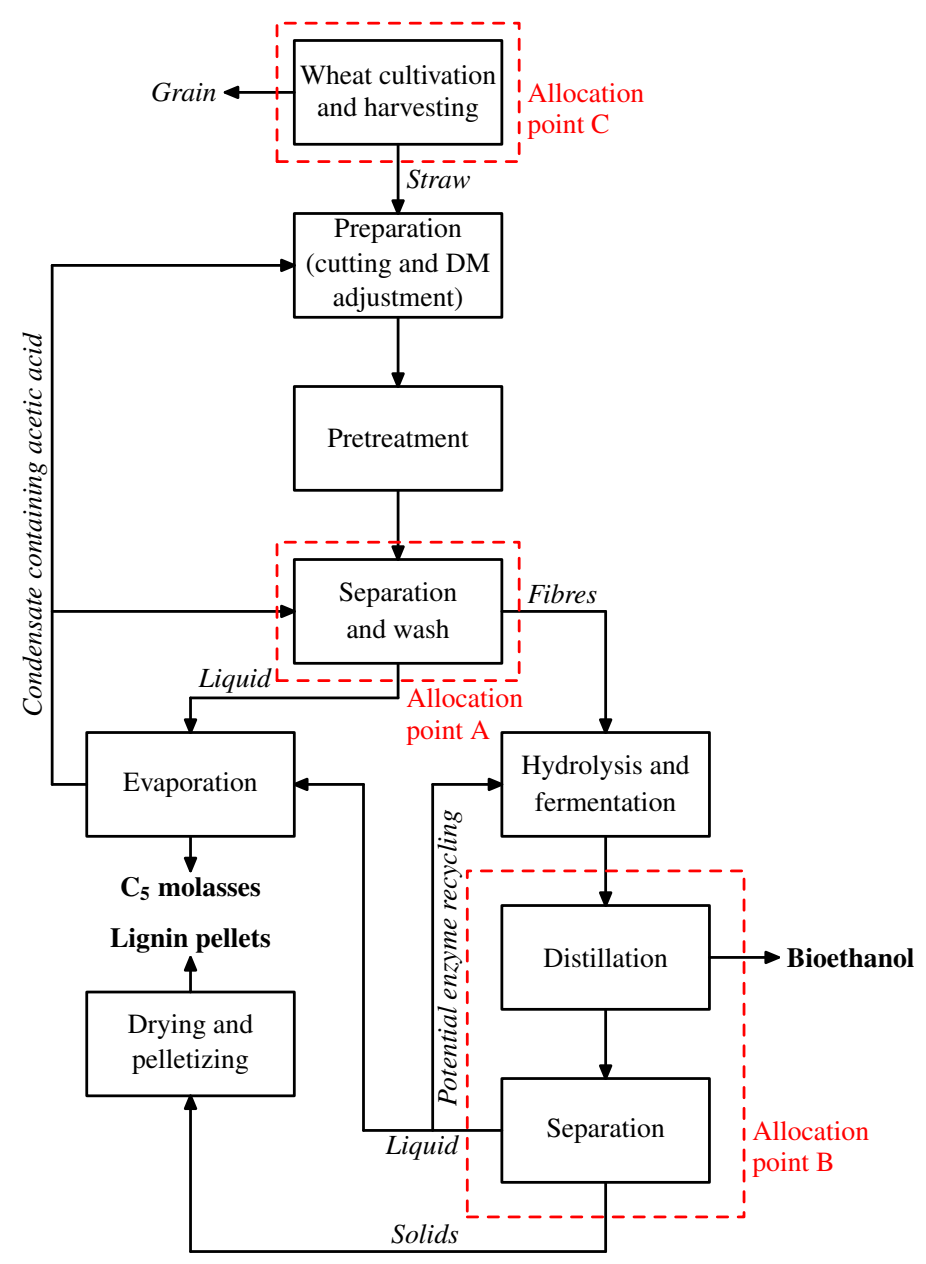


Figure 3

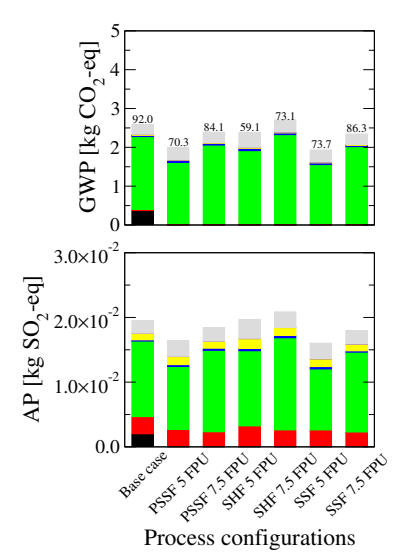

(a) Cellic CTec 2, 20\% DM

$\omega$
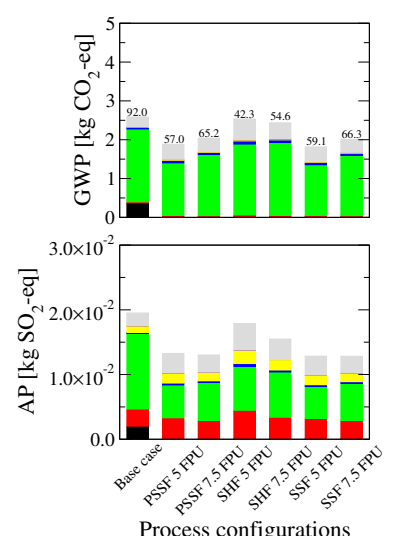

(d) Celluclast, 20\% DM

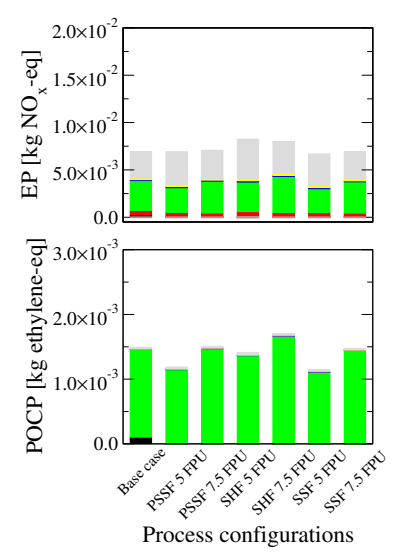

Process configurations

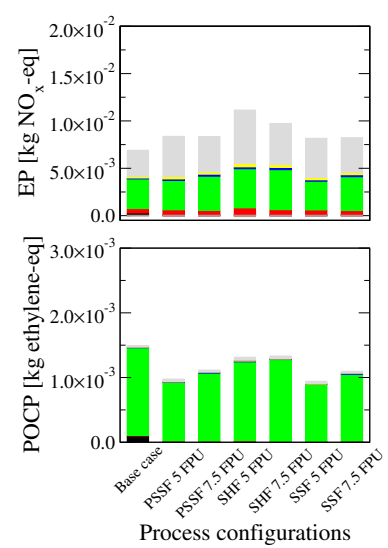

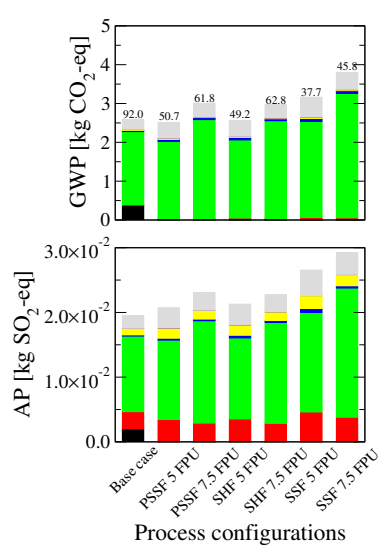

(b) Cellic CTec2, 30\% DM

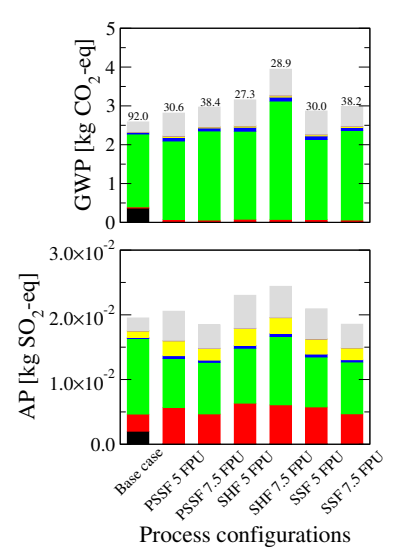

(e) Celluclast, 30\% DM
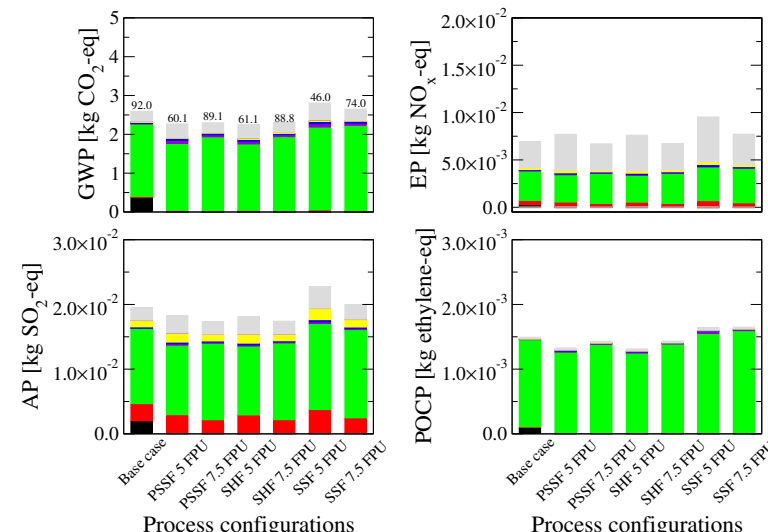

(c) Cellic CTec2, 30\% DM with PEG addition

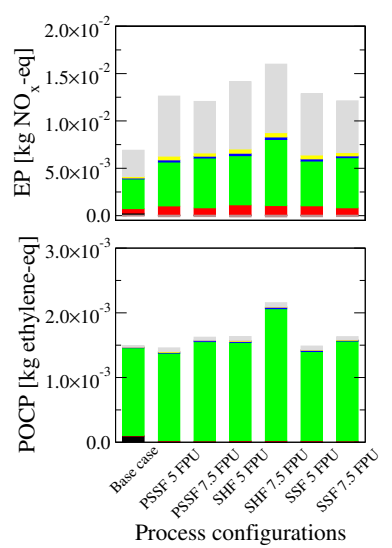

\begin{tabular}{|l|} 
Use of fossil fuel for process energy \\
Combustion of lignin for process energy \\
Enzyme production \\
PEG production \\
Production of additional chemicals \\
Straw pretreatment \\
Straw preparation \\
Straw cultivation \& harvesting \\
\hline
\end{tabular}
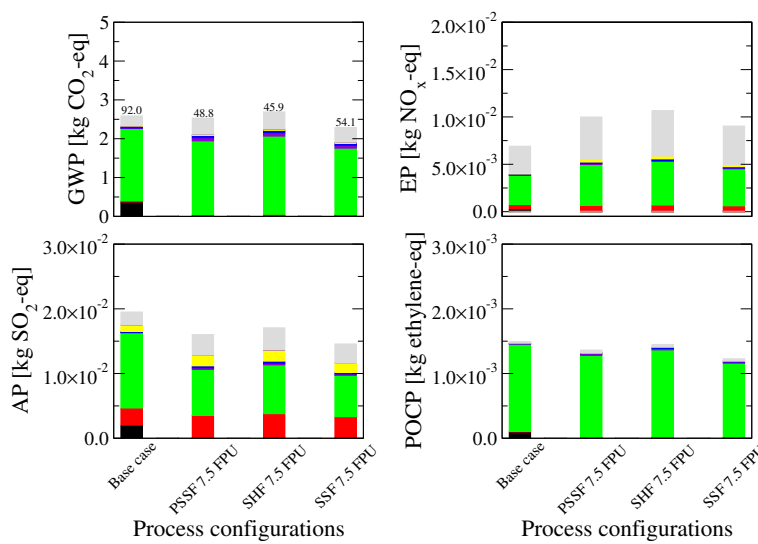

(f) Celluclast, 30\% DM with PEG addition 
Figure 4

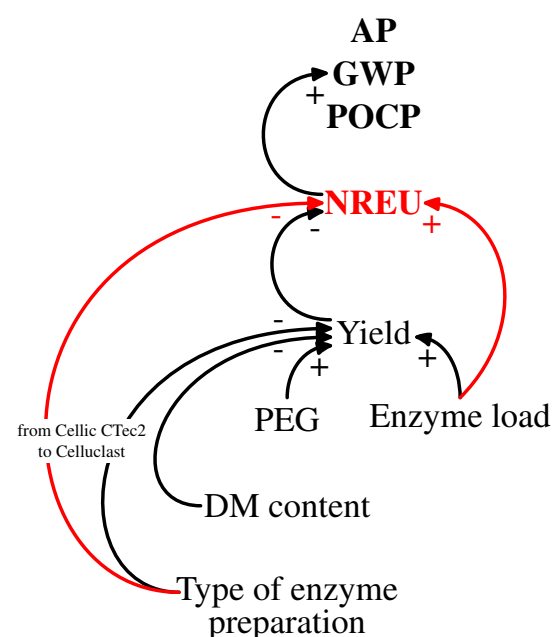

(a) Causal diagram for GWP, AP and POCP

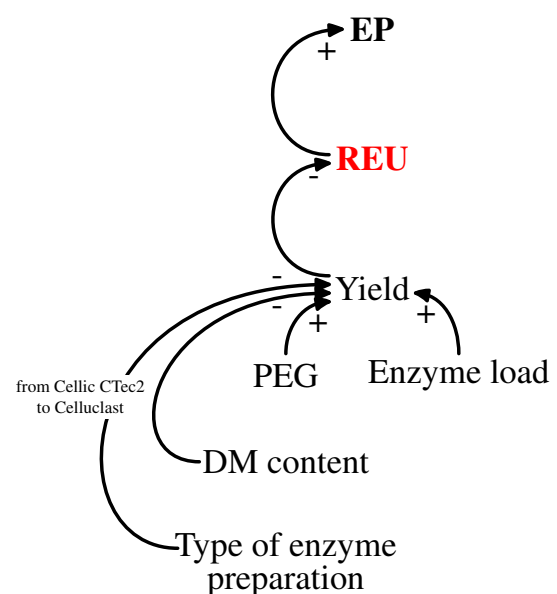

(b) Causal diagram for EP 
Figure 5

a.

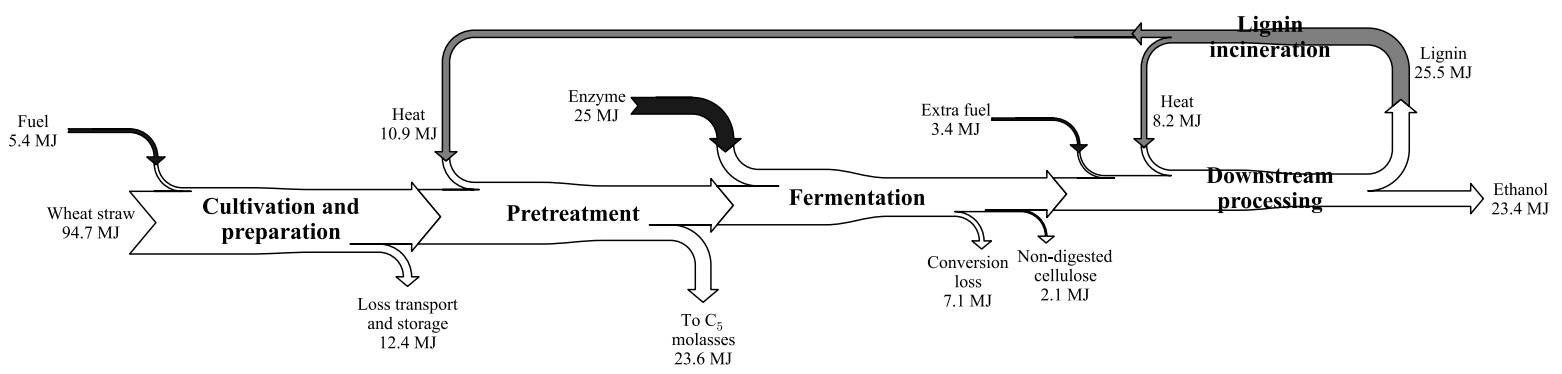

b.
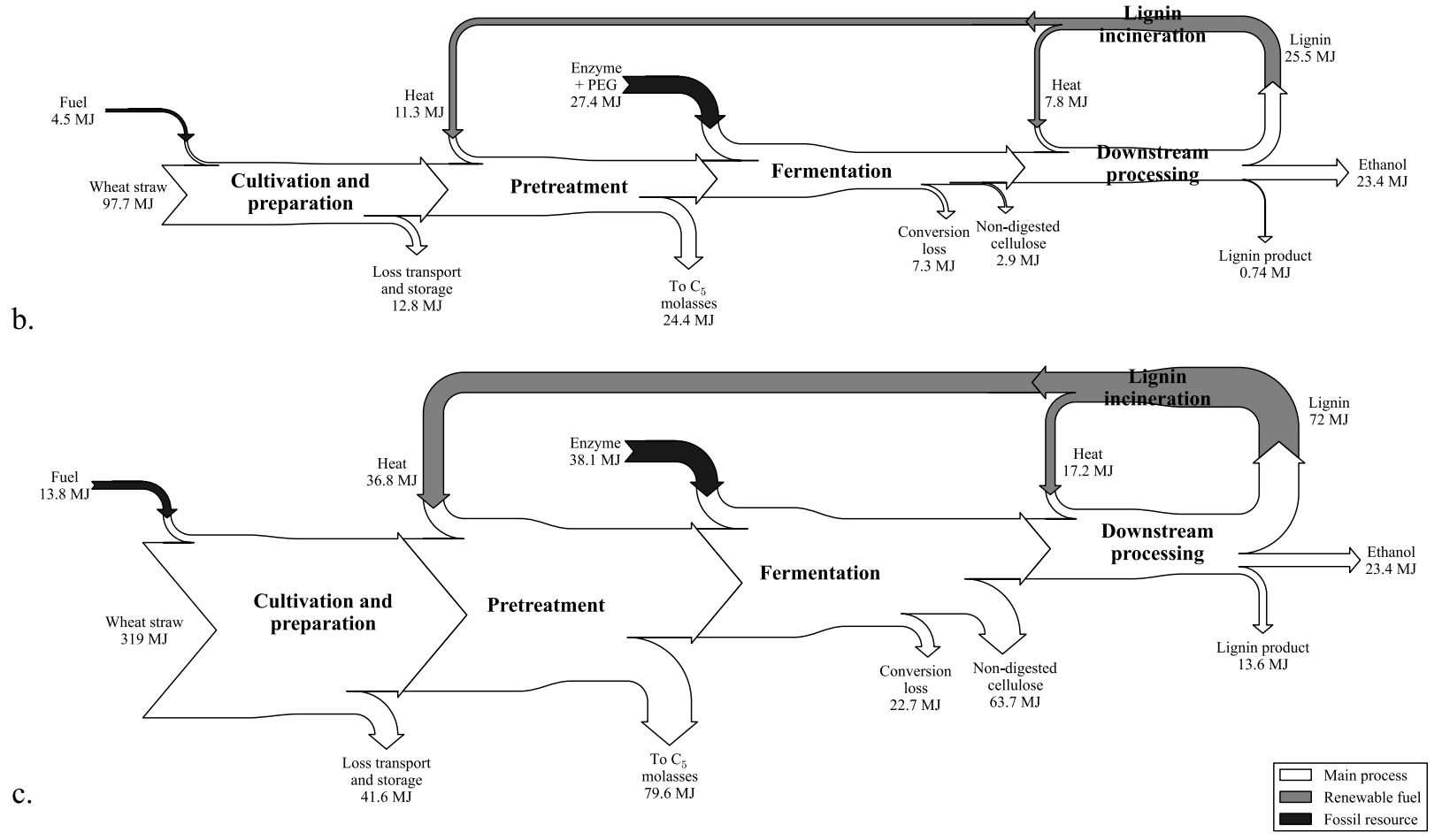


\section{Figure 6}
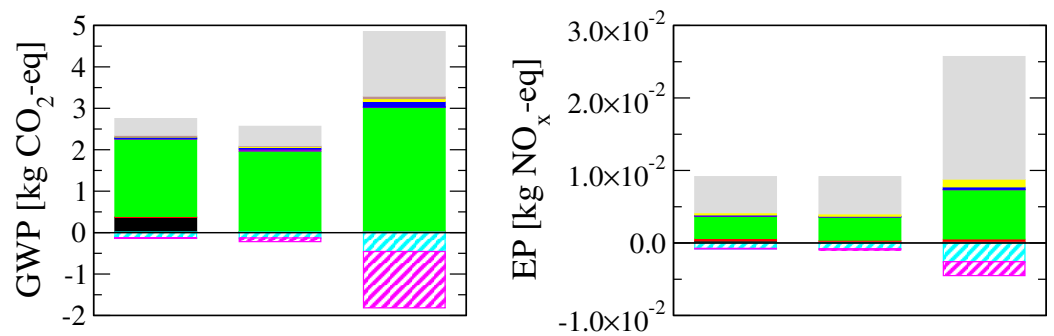

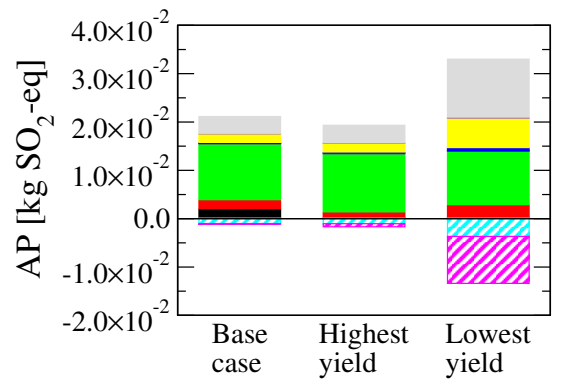

Process configurations

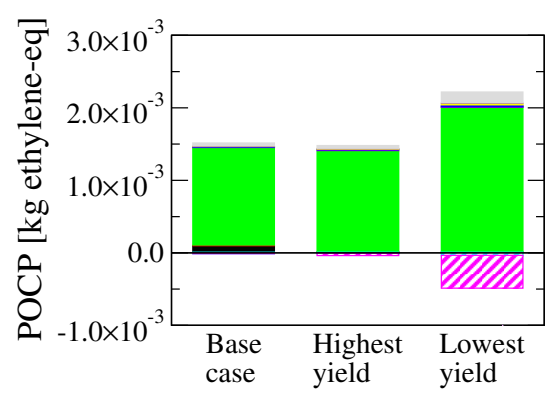

Process configurations
Use of fossil fuel for process energy

Combustion of lignin for process energy

Enzyme production

PEG production

- Production of additional chemicals

Straw pretreatment

Straw preparation

Straw cultivation $\&$ harvesting

Avoided emission due to $\mathrm{C}_{5}$ molasses production

Avoided emissions due to lignin production

Base case $($ yield $=92 \%)-10 \%$ DM, Cellic CTec2

7.5 FPU, all process strategies

Highest yield (yield $=89 \%$ ) $-30 \%$ DM, Cellic CTec2

7.5 FPU, PSSF, PEG addition

Lowest yield (yield $=27 \%$ ) - 30\% DM, Celluclast 5 FPU, SHF 